\section{内陸貯木場の性格}

\section{四津 隆一}

わが国に扣ける眝木場の機能をみると，運材 の途中に介在する結節点の役割を果たするの と, 運材の終点に位置する製材・合板・紙パル プ工場に付属して，すでに工場設備の一部之な っている詝木場の両者がある。

後者の機能をもつ眝木場は，近年若干の地理 学研究のなかで, 臨海工業地域の一環として, また木材港の港湾設備または木工団地の箘成要 素といら点から，関心をよせられはじめた（小 沢1965，日本工業立地七ン夕ー1968，四津1909)。これ に対して前者に関する地理学的研究は，筆者の 管見によれば，汪とんど見あたらないよらであ る。これは工場または港湾に付随する広大な貯 木場にくらべて，狭小ならえに散点的に分布 し，しかも近年交通条件の整備とともに，石の 重要性がやや低下して閔心を集め得なかった理 由によると考えられる。

結節的機能をもつ眝木場は，奥地林の伐採に 続く運材の際，トラック林道之森林軌道の接点 または両者と国鉄などの接点に立地するもので あって，位膡からい总ば内陸眝木場が大部分を 占めている。一方内陸眝木場は, 広義の林道の 一部とみなされて，多くの場合大規模な林業企 業体の施設となっている。この点国有林は，わ が国に打ける大部分の奥地林を統括管理すると ともに，国はわが国の最大の山林地主であるか ら, 内陸眝木場の概括的性格を国有林に求める ことができよう。

すなわち，わが国の国有林に打ける眝木場 は774. 28ha（1967 年）であるが，数年前の 997.74ha（1960 年）にくらべて娍少の傾向にあ り,この推移を内陸眝木場と密接な関係をむつ 林道との関係についてみると，林道延長はここ 数年で $25,003 \mathrm{~km} \quad$ (1960 年) から 26,549km （1967 年）と伸展傾向にあって，内陸眝木場面 積の推移とは対照的である。林道を森林軌道之 自動車道の 2 つに分汁ると，森林軌道は国有林 に多く敷設され，民有林における軌道延長の約

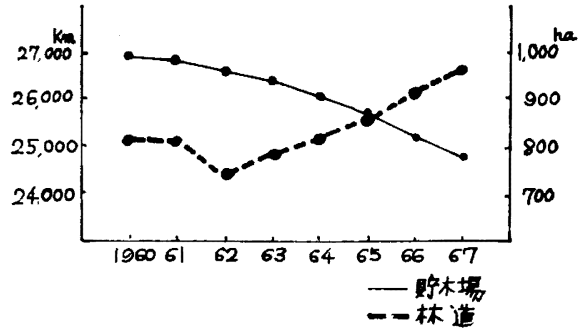

国有林年次別林道と貯木場面稳の推移

30 倍であって，この森林軌道はここ数年間で みると, 1 年に $500 \sim 600 \mathrm{~km}$ の割合で短縮して いるのに対して，自動車林道は 1 年に $1,000 \mathrm{~km}$ 以上ずつ伸展している。このよ5に運材体系は 同一の運搬機関に統合されて，途中に位置する 町木場の存在理由が薄弱になってきたことを意 味するといえる。

しかし以上は日本全体の内陸詝木場を概観し た軥合であって，地域的にみると北海道の胴体 部や東北地方では貯木場の縮小, 林道の伸展が 藷しく，一方北海道の肢節部や関 西 以西の大 阪・高知・熊本営林局管内では，あまり变化が みよめられない。さらに微視的に秋田県を例に とってみると，秋田スギ地域の上小阿仁・合 川・藤里の 3 営林署管内と, 大曲・角館営林署 管内などの広葉樹地域では，全国的傾向と反対 に眝木場面積が拡大している。これは奥地林の 伐採が進んでいる地域また忚林道の分岐が著し く林道網の整備が不十分な地域であって，現状 では眝木場の縮小が困難なためであると考えら れる。

(1970.2.18 受理)

付記本稿は東北地理学会 1968 年秋季学術大会（福 島）で発表した「眝木場立地の伝換」の前半をまとめ たものである。

小沢利雄（1965）：東京港港頭地域の眝木池と土地

造成について 日本地理学会 1965 年春季大会研 究発表要旨 地理評 38403

日本工業立地センター－（1968）：東京港木材関係用 地利用計画調查報告書

四津隆一（1969）：大船洨市における木材工業団地 の性格 東北地理 21 219

\title{
The Character of Inland Timber-yards
}

\section{Ryuichi Yotsu}

Timber-yards function in the transportation of timber as nodal points of forest roads and at the terminals of the transportation, too. The timber-yard makes an indispesanble element of factories dealing with timber, e.g. plywood, pulp industry etc. The inland timberyards belong to the category of the former function and are decreasing from year to year in number. This decrease of the inland timber-yards is due to recent development of roads for the transportation of timber, which reduced the necessity of timber-yards as depots. 